\title{
Biochemical Markers for Huntington's Chorea
}

\author{
D.R. MCLEAN and T. NIHEI
}

SUMMARY: The uptake of dopamine (DA) by platelet rich plasma was assayed in 11 patients with Huntington's chorea (H.C.). The results confirmed the previous observation that platelets from H.C. patients take up, at equilibrium, more dopamine than do platelets from normal control subjects. The mean difference was $50 \%$ higher at DA substrate concentrations of $0.11 \mathrm{mM}$.

However, attempts to confirm the higher $\mathrm{Na}^{+}-\mathrm{K}^{+}$ATPase activity of erythrocyte ghosts from Huntington's chorea patients were unsuccessful.

RESUME: L'Uptake de dopamine par le plasma riche en plaquettes fut mesuré chez onze patients avec chorée de Huntington. Les résultats confirment l'observation préalable qui indiquait que les plaquettes des patients choréiques captaient, en équilibre, plus de dopamine que les plaquettes des sujets contrôles. A une concentration de substrat dopamine de $0.11 \mathrm{mM}$ la différence moyenne fut de $50 \%$ plus élevée.

Cependant, il ne fut pas possible de confirmer l'activité supérieure en ATPase $\mathrm{Na}^{+}-\mathrm{K}^{+}$des erythrocytes de patients choréiques.

From the Division of Neurology, Faculty of Medicine, University of Alberta, Edmonton.

Reprint requests to Dr. D.R. McLean, 9-101 Clinica Sciences Building, The University of Alberta, Edmonton, Alberta, Canada T6G 2G3.

\section{INTRODUCTION}

It was reported that blood platelets from patients with Huntington's chorea (H.C.) take up more dopamine (DA) than do platelets from normal controls (Aminoff et al, 1974; McLean \& Nihei, 1977). Subsequently, Butterworth et al (1977) and Omenn and Smith (1978) studied the rate of DA uptake by platelets finding no difference in the platelets of H.C. patients. These conflicting conclusions appear to be due mainly to different experimental design. The former studies measured the DA capacity of platelets (amount of DA taken up at equilibrium) whereas the latter investigators determined the rate of DA uptake.

This paper reports the results of the DA uptake assay in 11 H.C. patients and confirms our previous observation of high uptake capacity.

Butterfield et al (1978) reported a $30 \%$ higher $\mathrm{Na}^{+}-\mathrm{K}^{+}$ATPase activity in erythrocyte ghosts from H.C. patients. We assayed the $\mathrm{Na}^{+}-\mathrm{K}^{+}$ATPase activity in erythrocyte ghosts from 10 H.C. patients, but found the activity to be normal.

\section{METHOD}

Dopamine Uptake Assay:

The H.C. patients consisted of 7 males and 4 females ranging in age from 35 to 73. The diagnosis was made on the basis of family history and clinical examination. All medication was stopped two weeks before blood was drawn. Blood samples collected in Vacutainer tubes (B-D Co. Canada) containing EDTA and sorbitol were centrifuged at $200 \mathrm{~g}$ for $5 \mathrm{~min}$ at room temperature. Platelet rich plasma (PRP) was recovered as the supernatant. Patient and control samples were assayed concurrently.

In the DA uptake assay, $10 \mu$ of the stock ${ }^{14} \mathrm{C}$-dopamine solution was added to each $\mathrm{ml}$ of PRP and incubated for 1 hour at $37^{\circ}$. The concentration of DA in PRP was adjusted by diluting the stock solution $(25 \mu \mathrm{Ci} / 55 \mu \mathrm{mol})$ to $0.55,0.275$ or 0.11 $\mathrm{mM}$. After incubation, $2 \mathrm{ml}$ of cold $0.9 \% \mathrm{NaCl}$ containing $0.15 \mu \mathrm{Ci} / \mathrm{ml}$ of ${ }^{3} \mathrm{H}$-inulin (Amersham Corp. Toronto/ Chicago) was added to $1 \mathrm{ml}$ of PRP, mixed by a vortex mixer, and the mixture was centrifuged at $8000 \mathrm{~g}$ for $10 \mathrm{~min}$ at $4^{\circ} .20 \mu \mathrm{l}$ of the supernatant and the pellet were dissolved respectively in $1 \mathrm{ml}$ of $1 \%$ sodium dodecylsulfate and the radioactivity was counted with $10 \mathrm{ml}$ of Aquasol II (NEN Canada, Que.) in a Bechman SL-200 Scintillation counter. The levels of tritium and carbon- 14 were calculated using two variable discriminators.

The purity of the ${ }^{14} \mathrm{C}$-dopamine (Amersham Corp. Toronto/Chicago) and ${ }^{12} \mathrm{C}$-dopamine (CalibiochemBehring Corp. Calif.) was examined using a thin layer chromatography in n-butanol-acetic acid-water.

$\mathrm{Na}^{+}-\mathrm{K}^{+}$A TPase Assay:

Erythrocyte ghosts were obtained by the procedure of Philipson and Baumgartner (1979). The ATPase activity was determined as the ouabain sensitive portion of ATPase. Two types of incubation mixtures were used to compare the $\mathrm{Na}^{+}-\mathrm{K}^{+}$ATPase of erythrocyte ghosts from H.C. patients and healthy volunteers; one described by Wins and Schoffniels (1966) and Butterfield et al (1978), and the other by Jarrett and Penniston (1978). The amount of inorganic phosphate released from ATP was measured by the method of Jarrett and Penniston (1978).

The protein content of erythrocyte ghosts was assayed using the biuret method. 
TABLE I

Summary of Dopamine Uptake Assay

\begin{tabular}{|c|c|c|c|c|}
\hline \multirow{3}{*}{$\begin{array}{l}\text { Concentration } \\
\text { of dopamine } \\
\text { added to PRP } \\
(m M)\end{array}$} & \multicolumn{2}{|c|}{$\begin{array}{c}n \text { moles of dopamine in } \\
10^{8} \text { platelets }\end{array}$} & \multirow{3}{*}{$\begin{array}{l}\text { difference } \\
\text { of means }\end{array}$} & \multirow{3}{*}{ p-value } \\
\hline & control & H.C. & & \\
\hline & $(n=13)$ & $(n=11)$ & & \\
\hline & mean S.D. & mean S.D. & & \\
\hline 0.550 & $2.58 \pm 0.65$ & $3.11 \pm 0.87$ & 0.53 & $<0.05$ \\
\hline 0.275 & $1.65 \pm 0.45$ & $2.21 \pm 0.77$ & 0.56 & $<0.025$ \\
\hline 0.110 & $1.00 \pm 0.26$ & $1.49 \pm 0.29$ & 0.49 & $<0.005$ \\
\hline
\end{tabular}

TABLE 2

$\mathrm{Na}^{+}-\mathrm{K}^{+}$ATPase Activity of Erythrocyte Ghosts

A TPase Activity (n moles/h.mg.) at $37^{\circ}$

Assay Method of

Assay Method of

Butterfield et al (1973) Jarret and Penniston (1978)

\begin{tabular}{l|l|r}
\cline { 2 - 3 } & $\begin{array}{l}\text { mean S.D. } \\
109 \pm 86(n=10)\end{array}$ & $\begin{array}{r}\text { mean S.D. } \\
\text { H.C. }\end{array}$ \\
CONTROL & $134 \pm 61(n=10)$ & $128 \pm 57(n=6)$ \\
\hline
\end{tabular}

\section{RESULTS}

Table 1 shows the average uptake capacity of DA by platelet rich plasma from controls at DA substrate concentrations of $0.11,0.275$ and $0.55 \mathrm{mM}$. Depending upon the DA concentration, uptake capacity was $20-50 \%$ higher in H.C. patients. The actual uptake amounts are depicted in Fig. 1 and indicate that 8 of 11 patients were outside 1 standard deviation of the mean at a substrate concentration of $0.11 \mathrm{mM}$. The results were less impressive at concentrations of 0.275 and $0.55 \mathrm{mM}$.

Table 2 summarizes the results of the erythrocyte ghost $\mathrm{Na}^{+}-\mathrm{K}^{+}$ATPase assay for both the Butterfield et al (1978) and Jarrett and Penniston (1979) methods. The erythrocyte ghost ATPase activity was the same in Huntington's chorea patients and normal controls.

\section{DISCUSSION}

The results of this study on the DA uptake capacity by platelets from H.C. patients were consistent with those reported by Aminoff et al (1974) and ourselves (1977). Butterworth et al (1977) reported that the rate of DA uptake by platelets from 3 unmedicated Huntington's chorea patients was not abnormal. Omenn and Smith (1978) also measured the rate of DA uptake in platelets from 3 patients finding no abnormality. The distinction between the uptake capacity and the rate of uptake has not been clearly recognized by these authors. It appears that the DA uptake capacity is elevated in the patient's platelets, but not the rate of uptake.

There has been much work done on the mechanism of serotonin (5HT) uptake and transport by platelets, but only a few studies on DA. The mechanism for 5HT and DA uptake is probably very similar, if not identical. DA is the substrate for a non-specific pump in the membrane of platelets which accumulates organic bases such as 5HT and nor-epinephrine (Solomon et al, 1970). Indeed, it has been shown that 5HT and DA are stored in the same intracellular vesicles of rabbit platelets (Da Prada \& Pletscher, 1969). Although DA uptake is inhibited by

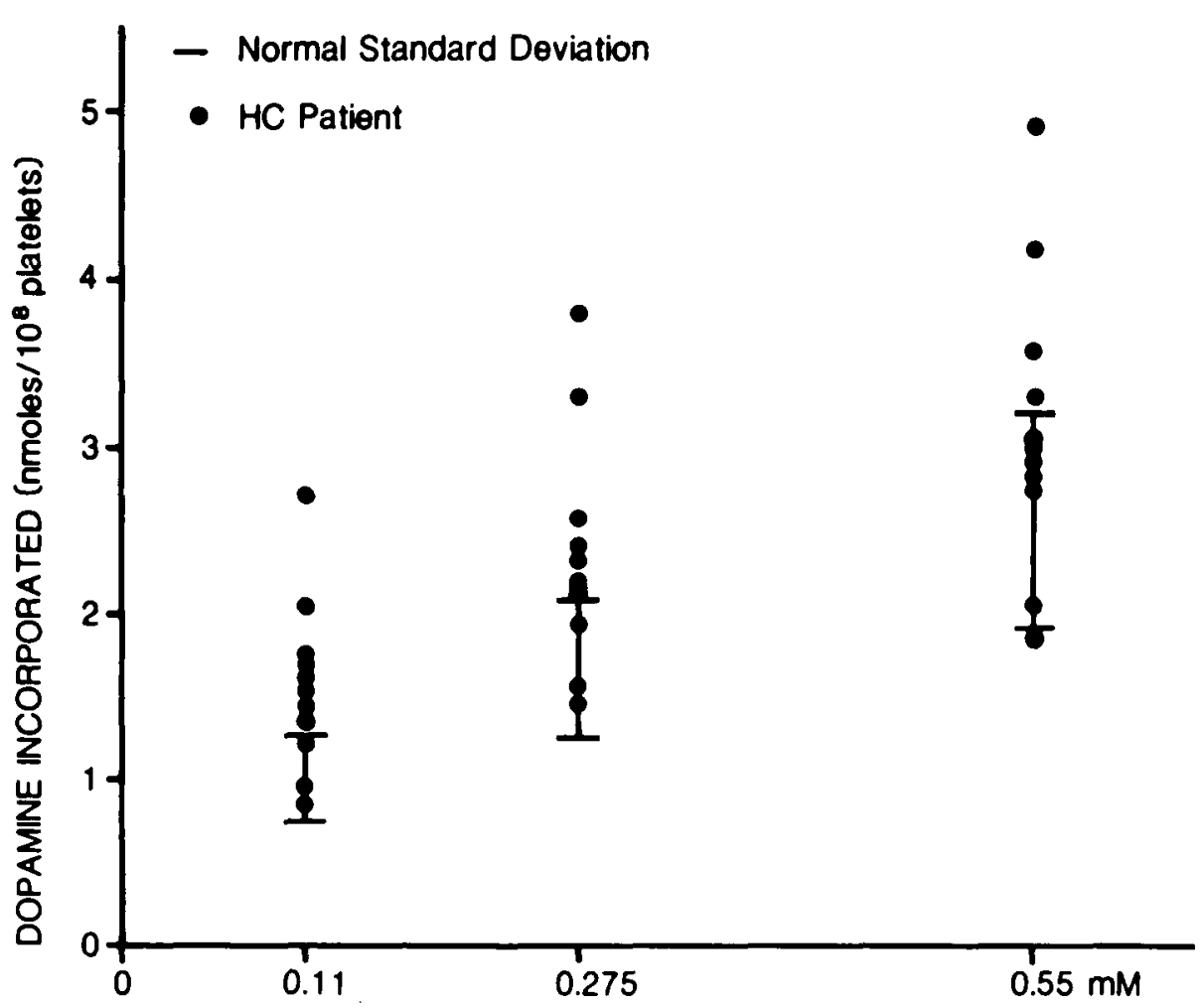

(DOPAMINE) added to PRP

Figure $I$ - Dopamine uptake by blood platelets from Huntington's chorea patients. The uptake values are determined after incubating PRP with ${ }^{14} \mathrm{C}$-dopamine for 60 minutes at $37^{\circ}$. The horizontal bars indicate the standard deviations of control uptake values. 
the case with chromaffin granule ghosts from adrenal medulla (Ingebretsen and Flatmark, 1979), $(\mathrm{NH})_{4} \mathrm{Cl}$ suppresses the DA uptake by platelets by collapsing the $\mathrm{pH}$-gradient across plasma membranes. These observations suggest that platelets take up DA through an energydependent and receptor-mediated mechanism, as well as through the passive diffusion. We have not determined whether altered active uptake or passive diffusion causes the increased DA uptake in platelets from H.C. patients.

The DA concentration (.55 $\mathrm{mM})$ in the substrate added to the platelet rich plasma has been criticized (Omenn and Smith, 1978) as being too high to reveal any characteristics of physiological importance. It is, however, at $10 \mathrm{mM}$ that DA saturates the $(\mathrm{NH})_{4} \mathrm{Cl}$ sensitive and energy dependent DA transport in chromaffin granule system (Ingebretsen and Flatmark, 1979). Thus, the DA concentration range used in our studies does not seem unreasonably high.

It is difficult to correlate the abnormal uptake of DA by platelets with the elevated levels of brain DA found in patient with H.C. (Bird \& Livesen, 1974). A common defect involving both platelets and certain central neurones in H.C. may explain these findings. It has been shown in rats that brain DA receptors increase after lesions of the nigrostriatal pathway but platelets have not been examined after central nervous system lesions. Changes in platelets would not be expected.

In this study, we could not confirm the results of Butterfield et al (1978) concerning the elevated $\mathrm{Na}^{+}-\mathrm{K}^{+}$
ATPase activity of erythrocyte ghosts from H.C. patients. The control $\mathrm{Na}^{+}$$\mathrm{K}^{+}$ATPase activity found by Butterfield et al (1978) was 66.1 \pm 6.4 whereas our level was $134 \pm 61 \mathrm{nmoles} / \mathrm{h} \mathrm{mg}$. The reason for this discrepancy is not clear. The $\mathrm{Na}^{+}-\mathrm{K}^{+}$ATPase activity of human erythrocyte ghosts ranges from 36 to $400 \mathrm{n}$ moles per $\mathrm{mg} \mathrm{hr}$ at $37^{\circ}$ (Albers, 1967; Zewall et al, 1973). This wide variation in normal may reflect the capricious nature of the ghost preparation.

Based on the results of this study, the DA uptake assay should yield a bimodal distribution when applied to patients at risk if the same uptake abnormality exists in the pre-symptomatic patient.

\section{ACKNOWLEDGEMENTS}

This work was supported by the Alberta Mental Health Advisory Council.

\section{REFERENCES}

ALBERS, R.W. (1967). Biological Aspects of Active Transport. Ann. Rev. Biochem. 36: 727-756.

AMINOFF, M.J., TRENCHARD, A., TURNER, P., WOOD, W.G. and HILLS, M. (1974). Plasma uptake of dopamine and 5HT and plasma catecholamine levels in patients with Huntington's chorea. Lancet 11 (7879) $1115-1116$.

BIRD, E.G., LIVERSON, L.L. (1974). Huntington's chorea - post-mortem measurement of glutamic acid decarboxylase. catecholacetyltranferase and dopamine in basal ganglia. Brain 97: 457-472.

BUTTERFIELD, D.A., OESWEIN, J.O., PRUNTY, M.E., HISLE, K.C., MARKESBERY, W.R. (1973). Increased sodium plus potassium ATPase activity in erythrocyte membranes in Huntington's disease. Ann. Neurol 4: 60-62.

BUTTERWORTH, R.F., GONCE, M., BARBEAU. A. (1977). Platelet dopamine uptake in Huntington's chorea and Gilles de la Tourettes syndrome: Effect of haloperidol. J. Can. Neurol. Sci. 4: 285-288.

CREESE, I., BURT, D.R., SNYDER, S.H. (1977). Dopamine receptor binding enhancement accompanies lesion induced behavioural supersensitivity. Science 147: 196-198.

DA PRADA, M., PLETSCher, A. (1969). Storage of exogenous monoamine and reserpine in 5HT organelles of blood platelents. Europ. J. Pharmacol. 7: 45-48.

INGEBRETSEN, O.C.. FLATMARK, T. (1979). Active and passive transport of dopamine in chromaffin granule ghosts isolated from bovine adrenal medulla. J. Biol. Chem 254: 3833-3839.

JARRET, H.W., PENNISTON, J.T. (1978). Purification of the $\mathrm{Ca}^{2+}$ stimulated ATPase activation from human erythrocyte. J. Biol. Chem. 253: 4676-4682.

McLEAN, D.R., NIHEI, T. (1977). Uptake of dopamine and SHT from patients with Huntington's chorea. Lancet 1 (8005) 249 250.

OMENN, G.S., SMITH, L. (1978). Platelet uptake of Serotonin and dopamine in Huntington's disease. Neurology (Minn.) 28: 300-303.

PHILIPSON, K.D., BAUMGARTNER, L.F. (1979). $\mathrm{Ca}^{2^{+}}-\mathrm{Mg}^{2^{+}}$ATPase activation: Its presence in human red blood cells and rabbit skeletal muscle. Biochem. Biophys. Acta 567: 523-528.

SOLOMON, H.M., SPIRIT, N.M., ABRAMS. W.G. (1970). The accumulation and metabolism of dopamine by the human platelet. Clin. Pharmacol. Therapeu. 11: 838-845.

STOHL, S.M., MELTZER, H.Y. (1978). The human platelets as a model for the dopaminergic neuron: Kinetic and pharmacologic properties and the role of amine storage granules. Neurology (Minn.) 28: 33 ! (Abst).

WINS, P., SCHOFFENIELS (1966). Studies on red cell ghost ATPase systems; Properties of a $\left(\mathrm{Mg}^{2^{+}}-\mathrm{Ca}^{2^{+}}\right)$dependent ATPase. Biochem, Biophys. Acta 120: 341-350.

ZEWALL, R.A., REELOFSEN, B., CALLEY, C.M. (1973). Localization of red cell membrane constituents. Biochem. Biophys. Acta 300: 159-182. 